\title{
Adaptative responses of $E$. coli to marine environmental stresses: a modelling approach based on viability and dormancy concepts
}

\author{
Yvan MARTIN a, Marc TROUSSELLIER ${ }^{\text {b }}$, Jean-Luc BONNEFONT ${ }^{\text {a }}$ \\ a Institut océanographique Paul-Ricard, lle des Embiez, 83140 Six-Fours-les-Plages, France \\ ${ }^{b}$ Laboratoire d'hydrobiologie, UMR CNRS 5556, université Montpellier-II, 34095 Montpellier cedex 05, France
}

(Revised 7 August 1998, accepted 14 August 1998)

\begin{abstract}
In an attempt to synthesize conceptual and experimental information on the behaviour of enteric bacteria in seawater, a mathematical model has been developed. This model is based on changes in intracellular metabolisable components depending on physiological responses of the cell when subjected to nutrient starvation, salinity stress and solar radiation. Following a strategy which takes into account short- and mid-term physiological adaptation and reversal processes, the cells can develop in different states: culturable $\left(B_{1}\right)$, viable and definitively nonculturable $\left(B_{2}\right)$, and reversibly dormant $\left(\mathrm{B}_{3}\right)$ cells. Model parameters were deduced either from original microcosm experiments, from literature data or calibration procedures. Validation of the model was performed through specific data on the patterns of change in culturable cell abundances when Escherichia coli populations were subjected to separate or simultaneous experimental stresses. It was shown that model simulations fit these data satisfactorily. Simulation results clearly show the effectiveness of the antistress response and the importance of dormancy which confers higher resistance properties. The model also makes it possible to test the effect of the different stresses, and the role of pre-adaptation with regard to the dynanics of the different cellular states. (1) Elsevier, Paris
\end{abstract}

Escherichia coli / seawater / stress / cellular states / modelling

Résumé - Réponses adaptatives d'Escherichia coli aux stress environnementaux : une approche par modélisation basée sur les concepts de viabilité et de dormance. Pour synthétiser les informations conceptuelles et expérimentales sur le devenir des bactéries entériques en milieu marin, un modèle mathématique a été développé. Il est fondé sur l'évolution du compartiment des réserves intracellulaires métabolisables en relation avec les réponses physiologiques des cellules Iorsqu'elles sont soumises à une carence en substrat, au choc hyperosmotique et au rayonnement solaire. Suivant une stralégie qui prend en compte les réponses physiologiques à court et moyen terme ainsi que des processus de réversibilité, on a considéré que les cellules bactériennes pouvaient évoluer successivement dans différents états physiologiques : cultivables (cellules $B_{1}$ ), viables mais définitivement non cultivables (cellules $B_{2}$ ) et (ou) viables mais pouvant retrouver leur cultivabilité (i.e. dormantes) (cellules $\mathrm{B}_{3}$ ). Les paramètres du modèle ont été calibrés soit à partir de la littérature soit à partir de données originales issues d'expériences en microcosmes. La validation du modele a été réalisét à l'aide de données indépendantes concernant l'évolution des abondances des cellules cultivables d'E. coli soumis expérimentalement à des cffets séparés ou combinés des différents stress précités. Les simulations obtenues se sont ajustées correctentent aux données observées. Les résultats de différentes simulations ont montré clairement l'efficacité des réponses anti-stress et l'importance de l'état de dormance qui confère aux cellules présentant cet élat de plus fortes capacités de résistance. Le modèle a également permis de relativiser les effets des différents stress, d'apprécier l'effet de leur durée et de mettre en évidence le rôle important d'une éventuclle pré-adaptation sur le devenir des différentes catégories cellulaires. Les résultats obtenus plaident en faveur d'un investissement méthodologique pour pouvoir mieux mesurer les abondances des cellules $B_{2}$ et $B_{3}$. Les apports de ce type de modélisation au plan de l'appréciation des risques sanitaires ont également été évoqués. (C) Elsevier, Paris

Escherichia coli / eau de mer / stress / états cellulaires / modélisation 


\section{INTRODUCTION}

The fate of enteric bacteria in the marine environment has long been studied, but since the 1980 s, our concepts of the behaviout of these bacterial cells has radically changed.

First proposed by Stevenson [4]], the dormancy concept has replaced the notion of mortality: in response to different environmental stresses, cells may enter the viable but non-culturable (VNC) dormant state $[20,45]$. This is of particular public health interest because pathogenic bacteria which enter this non-culturable state are undetectable through standard bacteriological methods.

The discovery of the VNC state gradually led to the study of survival strategy responses for enteric and autochthonous aquatic bacteria $[28,38]$, especially in the case of nutrient deprivation $[29,30]$.

In seawater, the behaviour of allochthonous bacteria depends on physical processes (dilution, dispersion, sedimentation), environmental conditions (temperature, salinity, light, oxygen, nutrient levels) acting on physiological cell status, and biotic factors such as grazing that, for some authors [40], were considered as the most significant factor in the "physical" disappearance of bacterial cells.

The most obvious response of cells subjected to adverse conditions is the loss of culturability on agar culture media. The timing of entry into the nonculturable state depends on the nature and intensity of the stress factor: cells exposed to solar radiation exhibited a rapid decrease in culturability $[3,37,43]$ which is partly the consequence of reactive oxygen species formation $[8,19]$. A dramatic decrease in culturability was observed when adverse marine environmental stresses (nutritional, osmotic, oxidative etc) were simultaneously applied [10]. In this case, $T_{90}$ values (time required to obtain $90 \%$ of nonculturable cells) are very short, from 1 to $2 \mathrm{~h}[4,35]$. Nutrient addition slows down the loss of culturability, showing that cellular responses depend on cell energetic status [4].

Apart from culturability loss, other physiological stressresponses, reported in the literature, may be summarised as a two-step strategy:

- short term multiple stress resistance that may be induced by different adverse conditions. This response may be developed within $4 \mathrm{~h}$ of the onset of nutrient deprivation [21] and induces different adaptative mechanisms: oxidative stress resistance, DNA repair and pro- tection systems (e.g. through Dps DNA-binding protein), thermotolerance, osmoprotectant synthesis and accumulation, etc. Induction of this response when cells enter the stationary phase could explain better survival of cells from this growth phase in seawater compared to exponential phase cells $[15,16,18,19,43]$.

- a less rapid response that leads to the VNC state and to dormancy which appeared reversible, at least under some environmental conditions. The characteristics of this cellular state have been well summarised by Oliver [33]: VNC cells exhibit a very low metabolic activity and seem to be capable of long term resistance under adverse conditions. If nutrient deprivation alone implies a slow increase of VNC cells, seawater salinity and solar light exposure accelerate this phenomenon [3].

Thus. our knowledge of the behaviour of enteric bacteria in seawater has greatly increased as a general picture of their stress responses emerges from the literature. However, behaviour models for enteric bacteria have been mainly based on culturable cell data and on statistical bases to try to link changes in environmental factors and culturable cell counts $[2,4,5]$. So far, no mathematical model has, to our knowledge, taken into account adaptative or survival processes for enteric bacteria in seawater, the resulting cellular states and their respective fate. It is such a model that we have developed within the framework of the Programme National d'Océanographie Côtière.

\section{MODEL DESCRIPTION}

\subsection{Hypotheses}

We considered that the fate of the cells was dependent both on their energetic state and their physiological responses to environmental stresses. The energetic model adopted is illustrated in figure 1. Like other authors [7, $11,12]$, we considered an intracellular compartment $q$, a fraction of cellular biomass that may be consumed by endogenous metabolism, in which energy is accumulated and used. The level of this compartment regulates cell behaviour according to three specific thresholds:

- $q_{M}:$ maximum level of $q$ which stops external substrate uptake;

$-q_{g}$ : threshold level allowing growth and cell division;

$-q_{m}$ : minimum level leading to cell autolysis. 

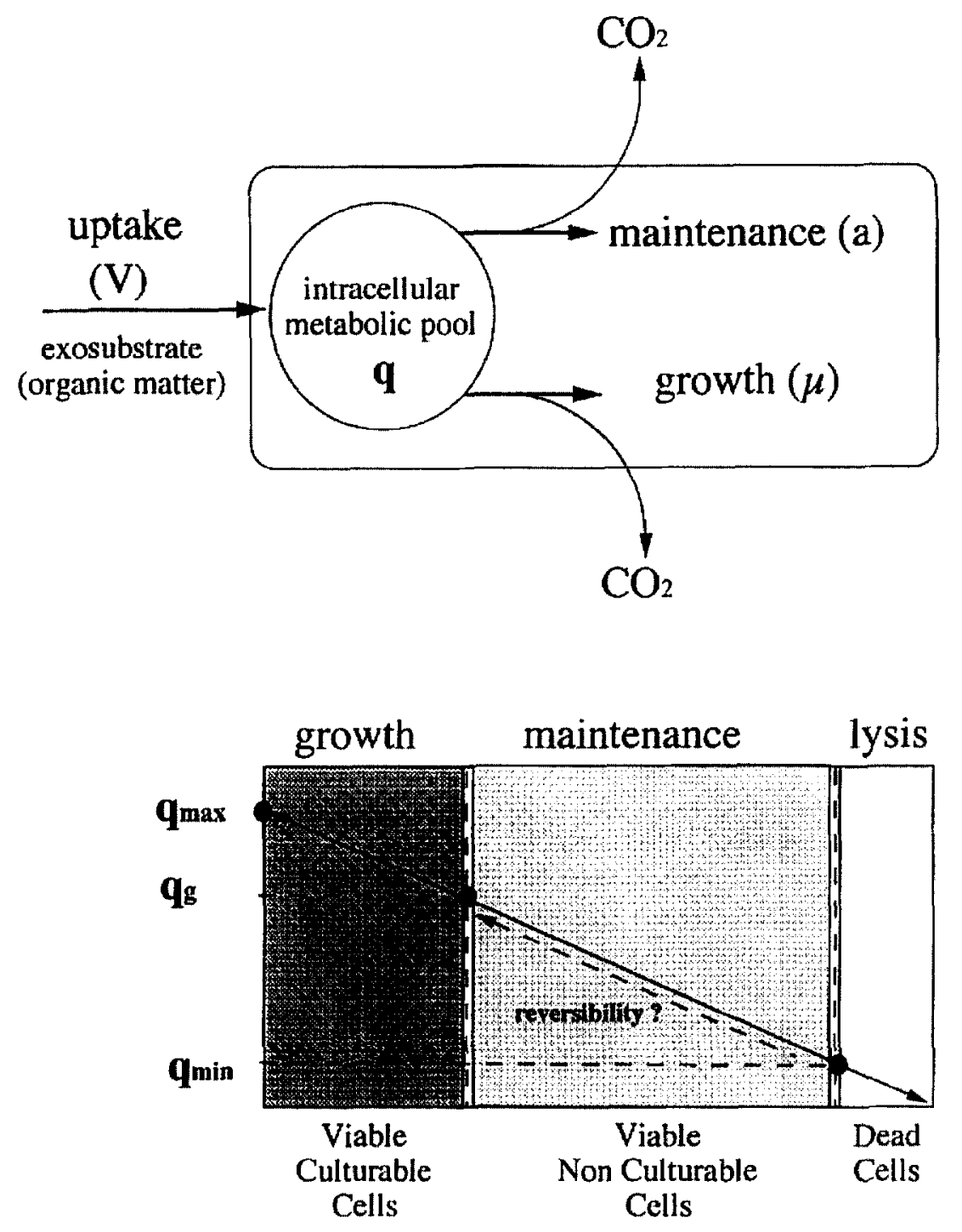

Figure 1. Illustration of energy model.

The intracellular pool $q$ is metabolised during the growth and survival phases. We have postulated that the cells are able to divide, but only if $q \geq q_{g}$. If $q<q_{g}$ cells are considered to be in the VNC state. Duration of the survival phase depends on the cell's ability to regulate its maintenance energy demand.

The second step in our conceptual approach was to complete this basic model by taking into account cellular stress responses (figure 2).

Considering an initial log phase population, where all the cells are culturable (exponential growth phase cells: $B_{1 E}$ cellular state), we hypothesized that the different marine environmental stresses could lead to three other different cellular states:

- viable. culturable but adapted cells $\left(B_{1 S}\right)$;

- viable but irreversibly non-culturable cells $\left(B_{2}\right)$;

- viable but temporarily non-culturable dormant cells $\left(B_{3}\right)$.

We assume that the processes leading to these cellular states are the following. In response to seawater stresses, a fraction of the initial cell population irreversibly becomes non-culturable $\left(B_{2}\right)$ and their proportion depends on the nature and the intensity of the imposed stress: the rate of culturability loss is low for nutrient dep- 


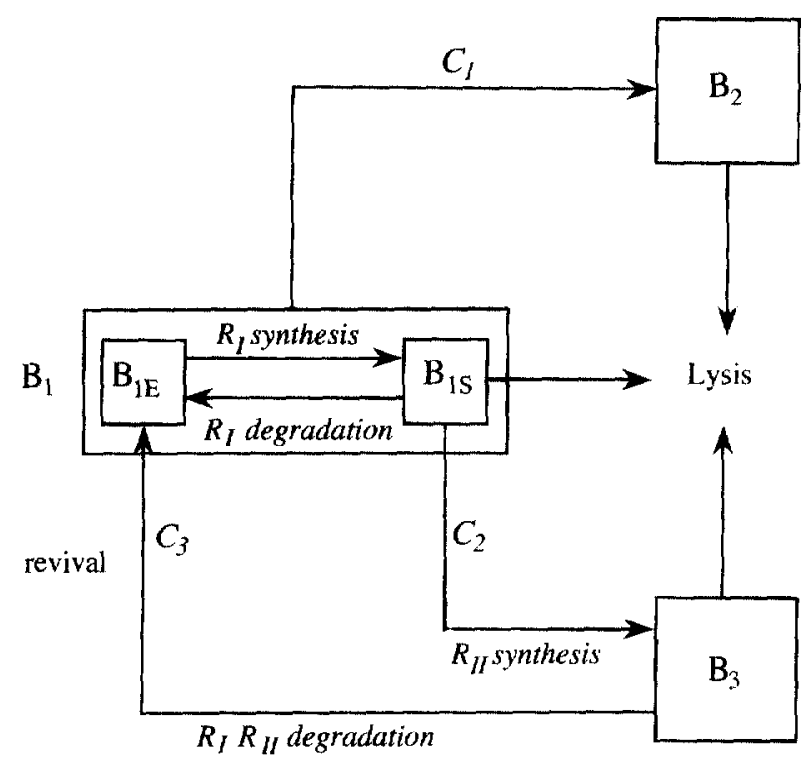

Figure 2. Conceptual model of physiological adaptations (see text for explanations).

rivation stress $\left(T_{90}>1\right.$ week), but higher when osmotic or solar radiation stresses are also applied $\left(T_{90} \approx 40\right.$ and $1 \mathrm{~h}$, respectively $[3,35])$. Other fractions of the initial population either maintain $\left(B_{1 S}\right)$ or temporarily maintain $\left(B_{3}\right)$ their culturability depending on their ability to develop physiological anti-stress responses. These responses need energy (obtained from the internal compartment $q$ ) and time to reach operational levels. We allowed two successive response levels:

$-R_{l}$ response: to resist, repair and adapt.

$B_{1 E} \log$-phase cells activate adaptative processes (stringent response, Rpos system etc.) which reduce their sensitivity to external stresses without completely eliminating their effects. Like Hengge-Aronis [21], we considered that this response takes place whatever the stress experienced by the cells, and consequently, it can be manifest in stationary phase cells. This is consistent with the fact that cells from stationary phase ( $B_{1 S}$ cells) exhibit better resistance (in terms of culturability loss) to different stresses than log phase cells $[14,43]$.

$-R_{l l}$ response: reversible dormancy.

We considered that this response takes place when $R_{f}$ response has already been synthesized, the main goal being to preserve the genomic information of the cells. The synthesis of $R_{l}$ effectors from internal compartment $q$ would induce DNA protection through DNA-binding proteins [1] or topological modifications of the nuclear region which, in turn results in temporary nonculturability due to the inability of the cells to divide as long as the $R_{l l}$ response is activated [17]. This response could take place whatever the environmental stress involved and leads to an increase of $B_{3}$ VNC bacteria with intact reversal potentialities as long as their internal compartment $q$ remains above the minimal level $q_{m}$, below which spontaneous lysis could occur. If these cells encountered more favorable conditions (e.g. nutrient increase, darkness), they could recover their culturability after degradation of $R_{l l}$ effectors. This seems to be an obligatory step to escape from the VNC state [32].

\section{MODEL FORMULATION}

The fate of cellular states depends on several interactive biological processes and environmental conditions. Seven functions have been used to describe the internal compartment and anti-stress response dynamics.

\subsection{Uptake of external substrates (V)}

A Michaelis-Menten saturation model was used, but under negative control due to the effects of salinity $(S)$, light $(L)$ and anti-stress response $R_{r}$. Following Di Toro [11], the uptake was considered to depend on the q level with a lowest uptake for dormant cells. This was done through a correction term $K_{q}$. The uptake remains active until the maximum level $q_{M}$ is reached, where $V=0$.

The uptake equation is:

$V=V_{M} \cdot A \cdot B \cdot C \cdot K_{\text {if }}$

with :

$A=O M /\left(K_{O M}+O M\right)$

and

$L=L_{M} \sin \left[\pi\left(t-t_{0}\right) /\left(t_{f}-t_{0}\right)\right]$

$B=1 /\left(1+S / K_{S} K_{S}^{\prime}\right) \quad K_{S}^{\prime}=A_{S}\left(R_{1}-R_{l m}\right)+1$

$C=1 /\left(1+U K_{L}+K_{L}^{\prime}\right) \quad K_{L}^{\prime}=A_{L}\left(R_{I}-R_{I m}\right)+1$

$K q=\left(q-q_{m}\right) /\left(q_{M}-q_{m}\right)$

where:

$V_{M}=$ maximum uptake rate $\left(\mathrm{h}^{-1}\right)$

$O M=$ external assimilable substrate concentration (mg. $\mathrm{L}^{-1}$ ) 
$K_{O M}=$ half saturation constant for external substrate $\left(\mathrm{mg} \cdot \mathrm{L}^{-1}\right)$

$S=$ salinity (dimensionless)

$K_{S}=$ salinity leading to a half $V_{M}$ (dimensionless)

$K_{S}^{\prime}=$ limitation coefficient for $S$ effect by $R_{l}$ (dimensionless)

$K_{L}=$ light amount leading to a half $V_{M}$ (Lux)

$K_{L}^{\prime}=$ limitation coefficient for $L$ effect by $R_{I}$ (dimensionless)

$L=$ total light amount ( $\sum$ lux) depending on maximum light intensity at midday U.T. $\left(L_{M}\right)$, on hour in the diurnal cycle $(h)$, and sun rise and set hours $\left(t_{0}\right.$ and $t_{f} U . T$.)

We also postulated a linear relationship beween $R_{I}$ level and the limitation coefficients for $S\left(K_{S}^{\prime}\right)$ and $L\left(K_{L}^{\prime}\right)$ effects :

$K_{S \text { or } L}^{\prime}=A_{S \text { or } L}\left(R_{l}-R_{l m}\right)+1$

with:

$R_{I}=$ level of $R_{I}$ (dimensionless)

$R_{l m}=$ minimum level of $R_{l}$ (dimensionless)

$A_{S \text { or } L}=$ constants for $S\left(A_{S}\right)$ and $L\left(A_{L}\right)$ effects deduced from experimental results

\subsection{Assimilation and growth}

The use of the internal nutrient pool $(q)$ for anabolic processes in $B_{1}$ cells was considered to follow a specific pattern of dynamics: contrary to the Monod model, we considered that available intracellular nutrient pool for growth requirements does not saturate the anabolic system. The growth rate $(\mu)$ of the cells varies in a linear way between the two limits $q_{g}$ and $q_{M}$, depending on $q$ level with $\mu=0$ when $q=q_{g}$. This formulation leads to a representation similar to that of Blackman [9]:

$\mu=\mu_{M}\left[\left(q_{1}-q_{g}\right) /\left(q_{M}-q_{g}\right)\right]\left(\mathrm{h}^{-1}\right)$

with: $q_{1}-q_{g}=$ nutrient pool available for growth

We also take into account a growth yield constant $Y_{g}$.

\subsection{Maintenance requirements}

In accordance with many literature reports [30], the endogenous metabolic rate was considered to be regulated by the size of the $q$ compartment. The maintenance rate $(a)$ would reach maximum values $a_{M}$ for $q=q_{M}$ and decrease linearly below this level: $a=a_{M} K_{q}$.

\subsection{Anti-stress responses}

$R_{I}$ and $R_{I /}$ anti-stress responses have been defined as intracellular compartments with arbitrary minimum and maximum levels to limit their efficiency. They are set at minimum values in non-stress conditions. Their synthesis and degradation take place at $P_{i}$ and $P_{i}^{\prime}$ rates, respectively. Synthesis requires time (between 2 and $4 \mathrm{~h} ;[21,25]$ ) and energy which is obtained from the $q$ compartment with a yield constant $\left(Y_{P i}\right)$. Degradation allows restitution of metabolites into the $q$ compartment. Synthesis and degradation processes have been considered to depend on several conditions: $R_{I}$ is synthesized and $P_{I}^{\prime}=0$ when cells experience nutrient deprivation or sufficient levels of salinity or solar radiation ( $S>10, L>4000$ lux). These levels have been deduced from experimental observations [35]. On the contrary, and if $q>q_{g}$, then $P_{i}=0$, which in turn leads to $R_{I}$ degradation ( $P_{I}^{\prime}$ rate). Synthesis of $R_{\|}$ response $\left(P_{I I}\right)$ begins only if $q<q_{g}$ and if $R_{I} \approx R_{I M}$. As for $P_{i}^{\prime}$, the $P_{I I}^{\prime}$ degradation rate becomes efficient only when external substrates are present and if light amount is low $(L<4000$ lux $)$. We do not think that salinity acts on $P_{I I}^{\prime}$ because $E$. coli growth in seawater supplemented with organic matter has long been demonstrated [6]

\subsection{Loss of culturability}

Two cases have been considered:

- (i) irreversible transformation of $B_{1}\left(B_{1 E}\right.$ and $\left.B_{1 S}\right)$ cells into $B_{2}$ cellular state ( $C_{1}$ rate), with a low constant basic rate $\left(C_{0}\right)$ increased by the effects of salinity $\left(C_{S}\right)$, sunlight $\left(C_{\mathrm{L}}\right)$, and their eventual interaction $\left(\beta C_{S} C_{L}\right.$ with $\beta=$ salinity-light interaction coefficient).

$C_{1}=C_{0}+C_{S}+C_{L}+\beta C_{S} C_{L}$

As in the case of substrate uptake rate, salinity or light effects are modulated by $R_{l}$ anti-stress response.

For salinity: $C_{S}=\mathrm{C}_{S M} S /\left(K_{S}^{\prime \prime} K_{S}+S\right)$

with:

$S=$ salinity (dimensionless)

$C_{S M}=$ maximum $\mathrm{B}_{2}$ transformation rate due to $\mathrm{S}\left(\mathrm{h}^{-1}\right)$

$K_{S}=S$ half rate constant $\left(\mathrm{g} \mathrm{L}^{-1}\right)$

$K_{S}^{\prime \prime}=$ attenuation coefficient of $B_{2}$ transformation rate by $S$ due to $R_{I}$ (see below). 
A similar expression was used for sunlight. For $K_{S}$ and $K_{l}$ coefficients. We adopted the same values as for nutrient uptake rate reduction and a linear relationship between $R_{/}$ level and attenuation coefficients of transformation rates:

$\left.K_{S \text { or } L}^{\prime \prime}=B_{S \text { or } L}\left[\left(R_{l}-R_{I m}\right) / R_{l}\right)+1\right]$

where $B_{S \text { or } L}$ is a constant derived from experimental results, for salinity or sunlight, respectively. We also postulated that $C_{1}$ transformation rate of $B_{1}$ into $B_{2}$ cells was limited by instantaneous repair of a small fraction of injured cells (SOS response) with a low efficiency $(\delta)$ if $R_{I}$ has reach a sufficient level $\left(R_{I} \leq 0.8 R_{I M}\right)$.

- (ii) reversible transformation of $B_{1}\left(B_{1 S}\right.$ only) cells into $B_{3}$ cell state due to $R_{/ /}$response, depending on a $C_{2}$ rate $\left(\mathrm{h}^{-1}\right)$ and $R_{l}$ level:

$C_{2}=C_{2 M}\left[1-\left(\left(R_{I M}-R_{I I}\right) / R_{I M}\right)\right]$

with $C_{2 M}=$ maximum $B_{3}$ transformation rate $\left(\mathrm{h}^{-\mathrm{j}}\right)$.

We have supposed that $R_{I I}$ becomes efficient only when it reaches a sufficient level $\alpha_{1}\left(\alpha_{1}=0.8 R_{I I M}\right)$.

\subsection{Revival of $B_{3}$ cells}

Escape from dormancy state depends on $R_{l l}$ degradation $\left(P_{I I}^{\prime}\right)$. Revival rate seems to be low $[22,33]$. This process starts only when $R_{l /}$ has reached a low level $\left(\leq \alpha_{2} R_{l / M}\right.$. where $\alpha_{2}$ is the $R_{/ /}$revival threshold coefficient).

The revival rate $\left(C_{3}\right)$ was formulated as:

$C_{3}=C_{3 M}\left[1-\left(\left(R_{I I}-R_{I I M}\right) / R_{I l}\right)\right]$ with $C_{3 M}=$ revival maximum rate, and two important conditions:

- if $O M=0$ and $L>4000$ lux then $C_{3}=0$.

Thus, we suppose that revival can occur even if cells are subjected to osmotic stress $(S>10)$ but not in nutrient deprivation conditions or when the light amount is high.

- if $R_{l l}>a_{2} R_{l M}$ then $C_{3}=0$.

In this way, we also suppose that $R_{I I}$ degradation, parallel to that of $R_{l}$, is not dependent on the $R_{l}$ level, in contrast to the synthesis of these responses.

\subsection{Cell lysis}

The model takes into account this process when $q$ tends to be close to $q_{m}$. We have defined a threshold value $a_{3} q_{M}$ under which lysis can occur at an identical rate $f_{M}\left(\mathrm{~h}^{-1}\right)$ for all cellular states. The assimilable lysed cellular fraction $(u)$ returns to the external substrate compartment, and so may be used by viable cells, especially in batch systems (microcosms) where it can support cryptic growth.

The system of differential equations used to translate the dynamics of model's components is reported in table $I$. Numerical values adopted for simulations are reported in table $I$.

\section{MATERIALS AND METHODS}

Bacteriological data, used for calibration and validation steps, have been obtained from $E$. coli survival experi-

Table I. System of differential equations used in the model.

variation of:

1. exosubstrate $(O M)=$ autolysis gain - uptake losses

$d O M / d t=u f B_{i}-V_{i} B_{i}$

2. intracellular metabolic pool $(q)=$ exosubstrate uptake - growth - maintenance $-R_{l}$ and $R_{\| l}$ synthesis $+R_{l}$ and $R_{I l}$ degradation

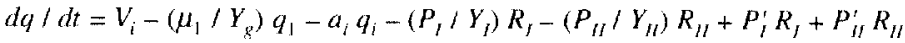

3. stress response $R_{l}=$ synthesis - degradation

$d R_{I} l d t=P, R_{I}-P_{I}^{\prime} R_{I}$

4. stress response $R_{I I}=$ synthesis- degradation

$d R_{l l} / d t=P_{l l} R_{l l}-P_{l l}^{\prime} R_{l l}$

5. $\underline{B}_{1}$ cells $=$ growth - maintenance - autolysis - loss by entry into $B_{2}$ and $B_{3}$ states + gain from $B_{3}$ revival

$d B_{1} / d t=\mu_{1} B_{1}-a_{1} B_{1}-f B_{1}-C_{1} B_{1}-C_{2} B_{1}+C_{3} B_{3}$

6. $\underline{\mathbf{B}}_{2}$ cells $=$ gain from $B_{1}-$ maintenance - autolysis

$d B_{2} / d t=C_{1} B_{1}-a_{2} B_{2}-f B_{2}$

7. $\underline{\mathbf{B}}_{\mathbf{3}}$ cells $=$ gain from $B_{1}-$ maintenance - autolysis - revival

$d R_{3} / d t=C_{2} B_{1}-a_{3} B_{3}-f B_{3}-C_{3} B_{3}$ 
Table II. Numerical values adopted for model variables and parameters. Values were derived from the literature (1.1: McGrew and Mallette [27]; 1.2: Hengge-Aronis [21]; 1.3: Oliver [33]; 1.4: Garcia-Lara et al. [13]; 1.5: Menon [26]; 1.6: Panikov [34]), experiments (2) or calibration procedures (3).

\begin{tabular}{|c|c|c|c|}
\hline variable/parameter & symbol & value & unit \\
\hline exosubstrate concentration (carbon) & $O M$ & $x$ & $\mathrm{mg} \mathrm{L}^{-1}$ \\
\hline maximum uptake rate $(2)$ & $V_{M}$ & 0.2 & $h^{-1}$ \\
\hline half saturation constant for $\mathrm{OM}(1.1)$ & $K_{O M}$ & 4 & $\mathrm{mg} \mathrm{L}^{-1}$ \\
\hline salinity & $S$ & $x$ & $\mathrm{~g} \mathrm{~L}^{-1}$ \\
\hline$S$ half rate constant (3) & $K_{S}$ & 20 & $\mathrm{~g} \mathrm{~L}^{-1}$ \\
\hline maximum light intensity & $L_{M}$ & $x$ & Lux \\
\hline I, half rate constant (2) & $K_{L}$ & 35000 & Lux \\
\hline maximum growth rate (2) & $\mu_{M}$ & 0.32 & $\mathbf{h}^{-1}$ \\
\hline$q$ maximum level (3) & $q_{M}$ & 0.5 & - \\
\hline$q$ minimum level (3) & $q_{m}$ & 0.001 & - \\
\hline 9 growth threshold (3) & $q_{g}$ & 0.475 & - \\
\hline growth yield (2) & $Y_{g}$ & 0.40 & - \\
\hline maximum specific maintenance rate (1.1) & $a_{M}$ & 0.01 & $\mathrm{~h}^{-1}$ \\
\hline$R_{l}$ synthesis rate $(1.2)$ & $P_{I}$ & 0.19 & $h^{-1}$ \\
\hline$R_{l}$ degradation rate $(1.3)$ & $P_{i}^{i}$ & 0.25 & $h^{-1}$ \\
\hline$R_{l l}$ synthesis rate $(1.3)$ & $P_{11}$ & 0.17 & $h^{-1}$ \\
\hline$R_{l l}$ degradation rate $(1.3)$ & $P_{\prime \prime}^{\prime}$ & 0.13 & $h^{-1}$ \\
\hline$R_{l}$ maximum level $(3)$ & $R_{l M}$ & 0.05 & - \\
\hline$R_{l}$ minimum level $(3)$ & $R_{I m}$ & 0.005 & - \\
\hline$R_{l l}$ maximum level (3) & $R_{l m M}$ & 0.005 & - \\
\hline$R_{l l}$ minimum level (3) & $R_{H m}$ & 0.0005 & - \\
\hline$R_{l}$ production yield ( 3 ) & $Y_{1}$ & 0.80 & - \\
\hline$R_{l I}$ production yield (3) & $Y_{l I}$ & 0.90 & -- \\
\hline minimum $B_{2}$ transformation rate (2) & $C_{0}$ & $10^{-5}$ & $h^{-1}$ \\
\hline maximum $B_{2}$ transformation rate due to $S(2)$ & $C_{S M}$ & 0.115 & $h^{-1}$ \\
\hline maximum $B_{2}$ transformation rate due to $L(2)$ & $C_{L M}$ & 1.115 & $h^{-1}$ \\
\hline$S L$ interaction coefficient (2) & $\beta$ & 7.5 & - \\
\hline instantaneous repair coefficient ( 3 ) & $d$ & 0.01 & - \\
\hline maximum $B_{3}$ transformation rate (1.3) & $C_{2 M}$ & 0.016 & $h^{-1}$ \\
\hline "revival" maximum rate $(1.2)$ & $C_{3 M}$ & 0.064 & $h^{-1}$ \\
\hline$R_{l f}$ action threshold coefficient ( 3 ) & $a_{1}$ & 0.8 & - \\
\hline$R_{l I}$ revival threshold coefficient $(3)$ & $a_{2}$ & 0.2 & - \\
\hline$q_{M}$ autolysis threshold coefficient (3) & $a_{3}$ & 0.01 & - \\
\hline maximum autolysis rate $(1.4,1.5)$ & $f_{M}^{\prime \prime}$ & 0.005 & $\mathrm{~h}^{-1}$ \\
\hline assimilable lysed cellular fraction (1.6) & $u$ & 0.3 & - \\
\hline
\end{tabular}

ments in batch microcosms using the experimental design and methodologies reported by Troussellier et al. [43]. To summarise, we used an $E$. coli strain $(E$. coli $\mathrm{K}-12$ MC4100). For the survival test, cells were grown at $37^{\circ} \mathrm{C}$, in mineral medium $\left(\mathrm{Na}_{2} \mathrm{HPO}_{4}, 6 \mathrm{~g} ; \mathrm{KH}_{2} \mathrm{PO}_{4}, 3 \mathrm{~g}\right.$; $\mathrm{NaCl}, 0.5 \mathrm{~g} ; \mathrm{NH}_{4} \mathrm{Cl}, 1 \mathrm{~g} ; 1 \mathrm{~mL}$ of $\mathrm{MgSO}_{4} 1 \mathrm{M}$, distilled water $1 \mathrm{~L})$ supplemented with glucose $\left(10 \mathrm{~g} \mathrm{~L}^{1}\right)$ and thiamine $\left(1 \mathrm{mg} \mathrm{L}^{-1}\right)$. Growth was monitored at $O D=$ $600 \mathrm{~nm}$ in a spectrophotometer Shimadzu UV1205 (Shimadzu corporation, Kyoto, Japan). Cells were collected by centrifugation $(4500 \times \mathrm{g}, 20 \mathrm{~min})$ during exponential phase. The pellets were washed twice in physiological water $\left(\mathrm{NaCl} 9 \mathrm{~g} \mathrm{~L}^{-1}\right)$; then suspended in $1 \mathrm{~L}$ sterile vials (microcosms) to a final concentration of $10^{6}$ to $10^{7}$ cells $\mathrm{mL}^{-1}$. For each survival experiment, eight microcosms were used; half were made of artiticial seawater $\left(\mathbf{S}^{+}\right)$ (Seasalt, Sigma) (Salinity $=38$ ), and half of artificial seawater diluted with sterile distilled water to reach a final salinity of $9\left(\mathrm{~S}^{-}\right)$. These microcosms were incubated either in the dark ( $\mathrm{L}^{+}$) or exposed to natural sunlight $\left(\mathrm{L}^{+}\right)$ and supplemented $(\mathrm{OM}+)$ or not $(\mathrm{OM}-)$ with organic matter (glucose, $50 \mathrm{mg} \mathrm{L}^{-1}$ final concentration) at a controlled temperature $\left(20^{\circ} \mathrm{C}\right)$. Changes in culturable counts, obtained by plating samples on nutrient agar (bioMérieux, France) incubated at $37{ }^{\circ} \mathrm{C}$ for $24 \mathrm{~h}$, and total direct counts, measured by epifluorescence micro- 
scopy following the method of Porter and Feig [36]

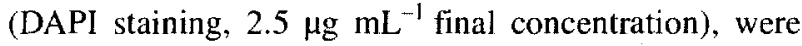
systematically monitored during two to five day experiments. In some survival experiments, we also measured the direct viable counts (DVC) by the method of Kogure et al. [23].

The numerical model has been developed with Stella II software (High Performance Systems Inc., NH, USA)

\section{RESULTS}

\subsection{Values of model parameters}

Some model parameter values were adopted from data in the literature (table $I I)$.

Others were estimated from experimental data sets concerning changes in abundance of E.coli cells (CFU) (table II). These data were obtained during microcosm experiments on marine stress effects (starvation: OM-; salinity: $\mathrm{S}^{+}$; solar light: $\mathrm{L}^{+}$) as described above. $\mathrm{CFU}$ counts were chosen because they correspond without ambiguity to $B_{1}$ cellular state defined in the model.

The components of $C_{1}$ rate (culturability loss rate) have been estimated from $T_{90}$ obtained under different experimental conditions as follows:

- constant basic transformation rate $C_{0}: \mathrm{OM}-\mathrm{S}^{-} \mathrm{L}^{-}$

- maximum transfomation rate due to salinity $C_{S M}: \mathrm{OM}^{-}$ $\mathrm{S}^{+} \mathrm{L}^{--}$

- maximum transformation rate due to solar light $C_{L M}$ : $\mathrm{OM}-\mathrm{S}^{-} \mathrm{L}^{+}$

- transformation rate due to salinity-light interaction $\beta C_{S} C_{L}: \mathrm{OM}-\mathrm{S}^{+} \mathrm{I}^{+}$

Modulation of $C_{1}$ rate by anti-stress response $R_{I}$ synthesis was estimated by comparison of $T_{90}$ values obtained on day 0 and for the following days during microcosm experiments.

Some other model parameter values, for which we do not have any experimental or literature based values, were estimated from calibration (table $I I$ ) to allow a good fit between simulated ( $B_{1}$ cells, total counts) and microcosm observed data. Four examples of observed CFU and simulated $B_{1}$ cell dynamics under different stress situations are presented in figure 3. A good agreement between simulation results and observed values is shown from the comparison of computed $T_{90}$ values from simulated and observed data (table $/ / T$ ).
Table III. Comparison of $T_{90}$ values deduced from observed and simulated data obtained during 4 different survival experiment conditions (OM-: no organic matter: S- $/+$ : salinity $=9 / 38 ; \mathrm{L}-/+$ : dark $/$ sunlight exposure, $L_{\mathrm{Max}}=30,000 \mathrm{lux}$ ).

\begin{tabular}{|c|c|c|}
\hline \multirow[t]{2}{*}{ Experimental conditions } & \multicolumn{2}{|c|}{$T_{90}(\mathrm{~h})$} \\
\hline & observed data & simulated data \\
\hline $\mathrm{OM}^{-} \mathrm{S}^{-} \mathrm{L}^{-}$ & 120 & 132 \\
\hline $\mathrm{OM} \mathrm{S}^{+} \mathrm{L}^{-}$ & 47.1 & 47.5 \\
\hline $\mathrm{OM} \mathrm{S}^{-} \mathrm{L}^{+}$ & 10.7 & 10.5 \\
\hline $\mathrm{OM}^{-} \mathrm{S}^{+} \mathrm{L}^{+}$ & 5.3 & 5.6 \\
\hline
\end{tabular}

\subsection{Validation of the model}

Two different experimental conditions have been used to validate the model on the basis of $T_{90}$ values of $E$. coli culturable cells.

First, two experiments were performed where $B_{1 E}$ (logphase) cells were subjected to nutrient deprivation (OM-) and osmotic stress $(\mathrm{S}+)$ under two different light-exposure conditions ( $L_{M}=60,000$ and 90,000 lux). Observed and simulated $T_{90}$ values over the two successive days of experiments showed a good agreement (table IV).

Table IV. Comparison of $T_{40}$ values deduced from observed and simulated data obtained during the first $\left(D_{0}\right)$ and second $\left(D_{1}\right)$ days in 2 different survival experiment conditions.

\begin{tabular}{ccc}
\hline Experimental conditions & \multicolumn{2}{c}{$T_{90}(\mathbf{h})$} \\
\hline & observed data & simulated data \\
\cline { 1 - 1 } $\mathrm{OM}^{-} \mathrm{S}^{-} \mathrm{L}^{+}$ & & \\
$\left.L_{M}=60,000 \mathrm{lux}\right)$ & & \\
$D_{0}$ & 3.55 & 3.01 \\
$D_{1}$ & 5.00 & 6.19 \\
$\mathrm{OM}^{-} \mathrm{S}^{+} \mathrm{L}^{+}$ & & \\
$\left(L_{M}=90,000 \mathrm{lux}\right)$ & & \\
$D_{0}$ & 1.45 & 2.34 \\
$D_{1}$ & 6.56 & 4.25 \\
\hline
\end{tabular}

Second, $E$. coli cells, previously incubated in seawater for $14 \mathrm{~h}$ either in the dark or not, were then subjected to sunlight exposure for $6 \mathrm{~h}$, to test the effect of pre-adaptation of cells. Similar $T_{90}$ values were obtained from observed and simulated data (table $V$ ).

These last results show clearly that the eventual pre-adaptation of the cells, allowing the $R_{I}$ response before sunlight exposure, leads to a significant increase in $T_{90}$ values. The model seems to take this important phenomenon into account well, as already described by other authors [18]. 

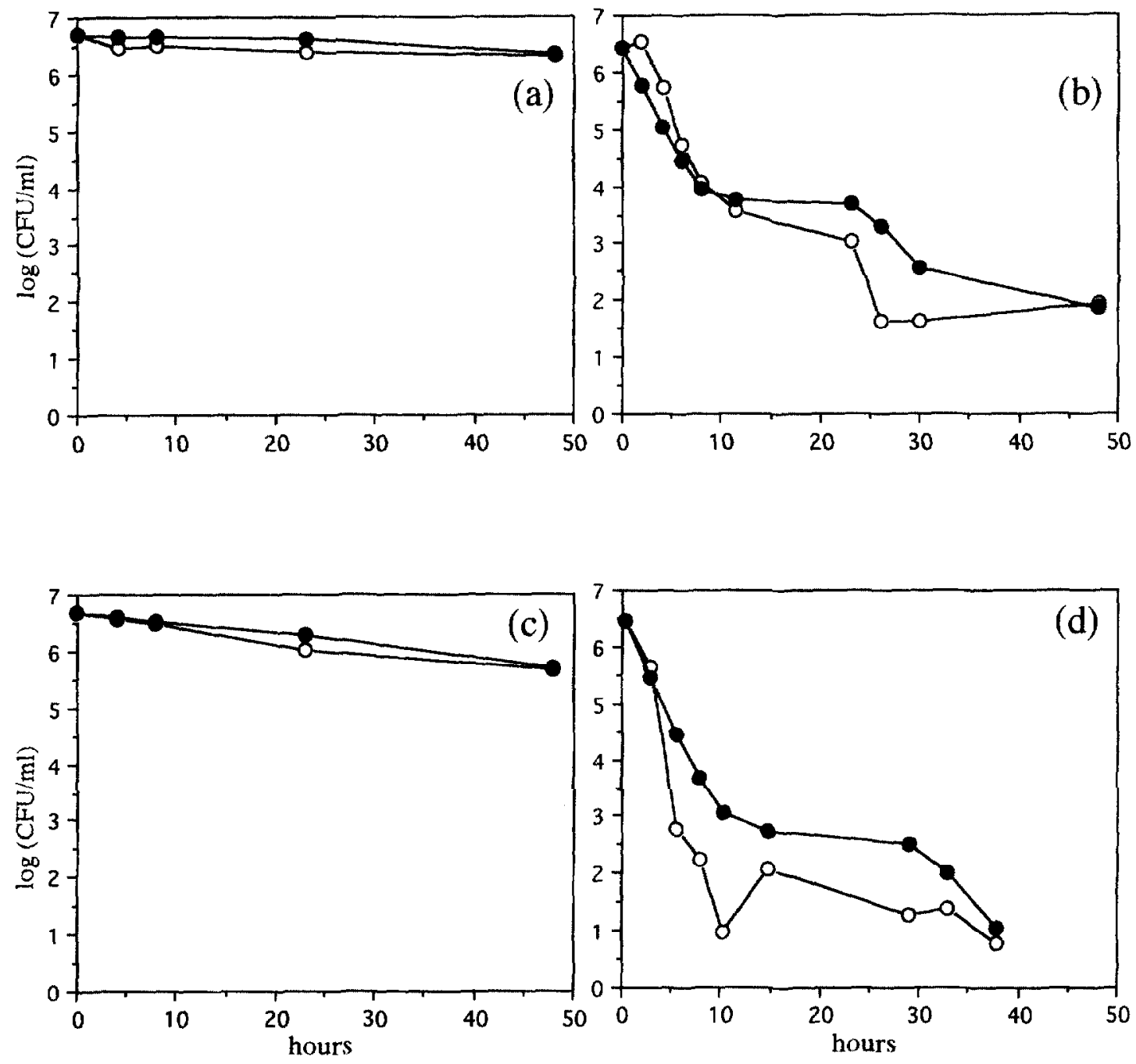

Figure 3. Changes in observed $(O)$ and simulated $(O)$ abundances of $E$. coli population submitted to different stresses in the absence of organic matter: (a) $S-$, L-; (b) $S-, L+$; (c) $S+, I-;$ (d) $S+, L+(S-/ S+$ : 9/38; $L-/ L+$ : dark/sunlight exposure).

We computed the correlation coefficient $(r)$ between observed and simulated changes in culturable $E$. coli $\left(B_{1}\right.$ cells) abundances for the different available comparisons $(n=10)$. We obtained significant $(P<0.01)$ or highly significant $(P<0.001)$ values for 8 comparisons, which makes us confident of the ability of the model to predict changes in the dynamics of $E$. coli cells.

\subsection{Simulation of the effects of some environmental variables on the fate of culturable bacteria}

Simulated effects of increasing amounts of organic matter in the presence of an osmotic stress ( $\mathrm{S}+$ ) or not (S-) for one day in darkness (L-) are illustrated in figure 4. The addition of small amounts of assimilable organic matter (such as glucose) leads to a decrease of the culturability loss rate. For concentrations $>150 \mathrm{mg} \mathrm{L}^{-1}$ we obtain a positive growth rate. However, growth rate values are expected to be lower in seawater: growth in seawater is possible albeit at a low division rate when compared to osmotically non-stressed cells. When cells are subjected to light exposure, the addition of organic matter does not allow an increase in culturable cell numbers but reduces the culturability loss rate.

We also tested the effect of different sunlight intensities on culturability loss rate without external organic matter. 
Table V. Comparison of $T_{90}$ values deduced from observed and simulated data obtained during a short $(6 \mathrm{~h})$ sunlight and salinity exposure experiment, without or with a pre-adaptation step in seawater and in the dark $(14 \mathrm{~h})$.

\begin{tabular}{|c|c|c|c|}
\hline \multicolumn{4}{|c|}{$T_{90}(\mathrm{~h})$} \\
\hline \multicolumn{2}{|c|}{ without preadaptation } & \multicolumn{2}{|c|}{ with preadaptation } \\
\hline $\begin{array}{c}\text { observed } \\
\text { data }\end{array}$ & $\begin{array}{c}\text { simulated } \\
\text { data }\end{array}$ & $\begin{array}{c}\text { observed } \\
\text { data }\end{array}$ & $\begin{array}{l}\text { simulated } \\
\text { data }\end{array}$ \\
\hline 5.7 & 3.7 & 11.7 & 12.5 \\
\hline
\end{tabular}

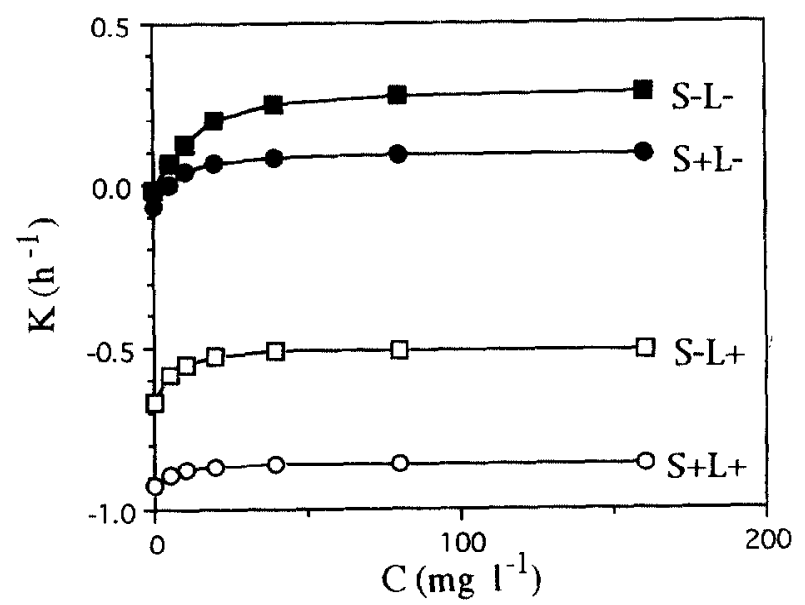

Figure 4. Simulation of the effect of organic matter concentration increase on the specific culturability loss rate $(K)$ of $E$. coli in different environmental conditions $(\mathrm{S}+/ \mathrm{S}-: 38 / 9 ; \mathrm{L}+/ \mathrm{L} \cdots$ : sunlight exposure/ dark).

During the first exposure ( $6 \mathrm{~h}$ ), there is a strong increase of culturability loss rate when light intensity increases. The relation follows a logarithmic model $(r=0.995$, $n=6, P<0.001) . T_{90}$ values change from $9 \mathrm{~h}$ for 10,000 lux to $2.3 \mathrm{~h}$ for 90,000 lux. During the following exposure, $R_{I}$ response leads to increased $T_{90}$ values which range from $25 \mathrm{~h}$ for 10,000 lux to $4.8 \mathrm{~h}$ for 90,000 lux, according to a linear model $(r=0.996, n=6, P<0.001)$.

\subsection{Dynamics of the different cellular states}

The simulated short term changes in the different cellular states are presented in figure 5. Wide differences in the fate of cellular states are apparent, according to the stresses applied. Irreversibly unculturable $B_{2}$ cells become quickly dominant with salinity and sunlight stresses. The proportion of dormant reversible $B_{3}$ cells remains very low when the initial population of $B_{1 E}(\log$ phase cells) is subjected to sunlight exposure. Their numbers are greater in the dark.

We also simulated the fate of cell type proportions for preadapted or not initial $B_{1}$ population. While unculturable $B_{2}$ cells represent the main cellular state in both cases after $24 \mathrm{~h}$ ( $>99 \%$ of the total population), an initial preadaptation of the cells seems to favourise not only the maintenance of $B_{1 S}$ cells as previously seen, but also the rise of dormant $B_{3}$ cells (simulated $B_{3}$ cells after $24 \mathrm{~h}$ without preadaptation $=0.0002 \%$; with preadaptation $=$ $0.05 \%$ ). These results have important public health implications: the behaviour of an $E$. coli population in seawater differs qualitatively and quantitatively if it was released in the evening, where cells may "benefit" from a preadaptation period during the night, or in the morning, when cells may be directly exposed to sunlight. The first case favours the appearance of $B_{3}$ dormant cells in surface waters, which are undetectable by conventional cultural methods.

\section{DISCUSSION AND CONCLUSION}

The "physiological adaptation" model developed here makes it possible to predict changes in the three considered cellular states occurring in relation with marine environmental stresses. It shows the relative contribution of each stress and the importance of cellular anti-stress responses. Simulation results suggest the preponderance of $B_{2}$ (viable but irreversibly non-culturable) cells during the first hours of stress exposure, especially in the case of sunlight.

In addition, the model clearly shows the effectiveness of the anti-stress response and the importance of dormancy which confers higher resistance properties. The question of whether this represents a stochastic or determinist property remains unclear $[24,42]$. This state only concerns a more or less important cell proportion depending on the nature and intensity of the stress and on the existence of a preadaptation period. These results open up a new approach to the VNC question, because so far, only $B_{3}$ cells have been considered to exhibit this property. This point is very important: public health implications will be very different depending on the selected model used as a predictive tool. Simulation results obtained with three different models applied to the same initial $E$. coli population submitted to the same environmental conditions, show serious discrepancies (figure 6). A $T_{90} / \mathrm{CFU}$ model (figure $6 a$ ) only predicting culturable cells (CFU) 

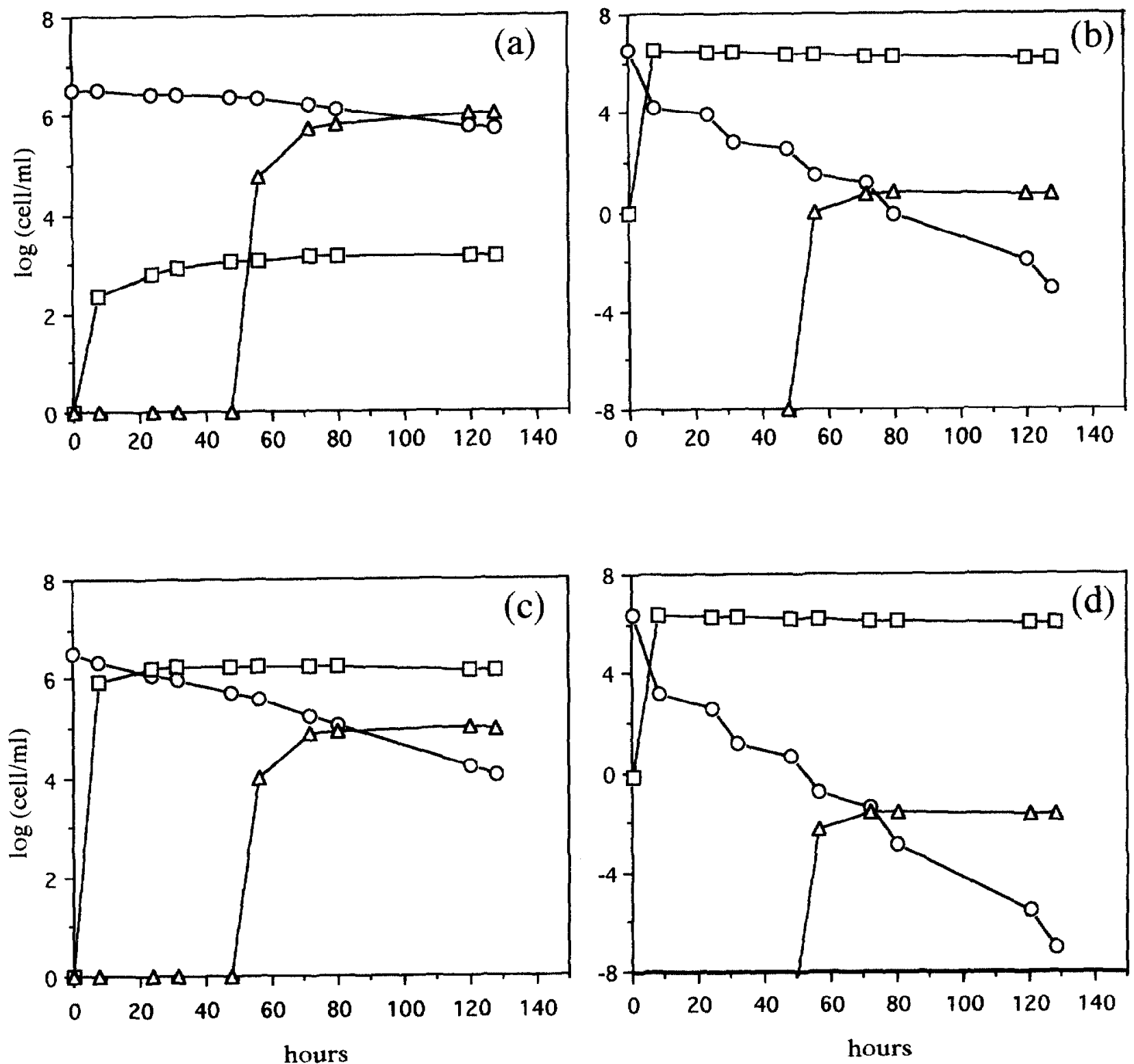

Figure 5. Simulation of the fate of the different cellular states $\left(B_{1}(O), B_{2}(\square), B_{3}(\Delta)\right)$ submitted to different stresses in the absence of organic matter: (a) $\mathrm{S}-, \mathrm{L}-$; (b) $\mathrm{S}-, \mathrm{L}+$; (c) $\mathrm{S}+, \mathrm{L}-$; (d) $\mathrm{S}+\mathrm{L}+(\mathrm{S}+/ \mathrm{S}-$; $38 / 9 ; \mathrm{L}+/ \mathrm{L}-$; sunlight exposure/ dark).

disappearance, which corresponds to the usual bacteriological standards, shows a fast and strong decrease in cell numbers and thus minimises health hazards. In contrast, a model based on dormancy entry of all the cells (VNC model, figure 6 b) maximises these hazards. In this case, grazing is the only way to reduce bacterial abundance. Our model (figure $6 c$ ), which predicts not only culturable $\left(B_{1}\right)$ but also reversible-dormant $\left(R_{3}\right)$ cell fates (i.e. the sum of cells with potential sanitary implications) leads to intermediary results, especially when the cells are released at the beginning of the night. This case corre sponds to a dark incubation condition allowing adaptative process to develop. However, even if culturable counts are now considered as questionable tools to monitor seawater health quality, it is important to know what kinds of non-culturable cells of pathogenic bacteria retain virulence [33], in order to be able to decide what kind of models allows a realistic appreciation of health hazards. 
(a) - T90/CFU model

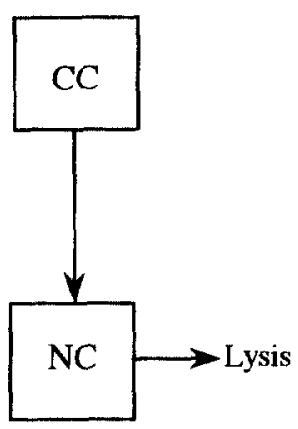

CC: culturable cells; NC: nonculturable cells $=$ dead cells

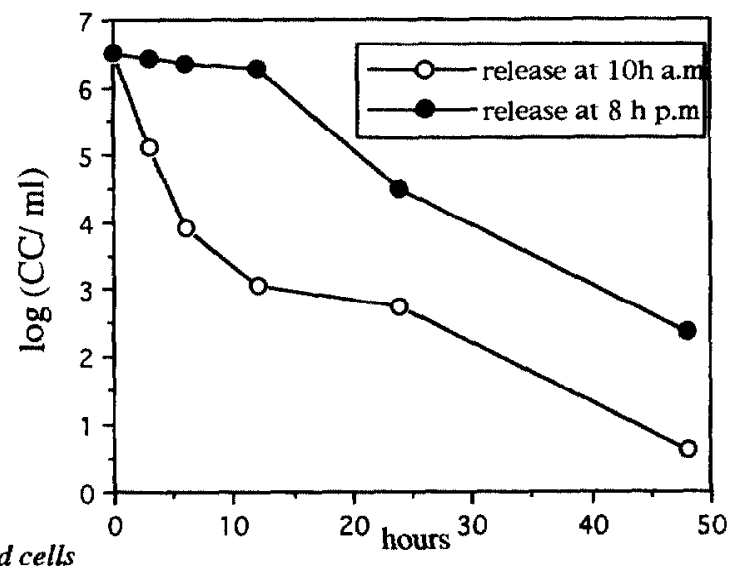

\section{(b) - VNC model}

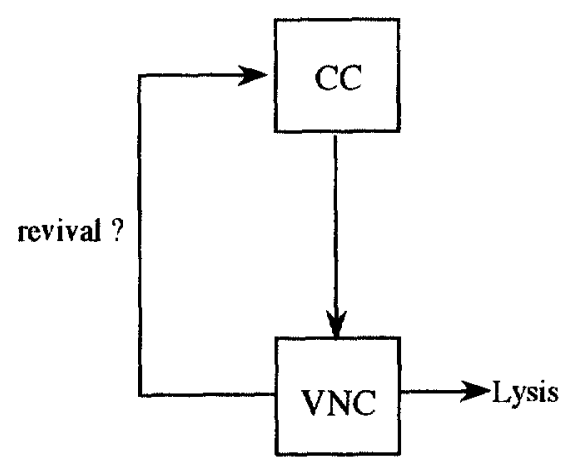

VNC : viable non-culturable cells

(c) - physiological adaptation model

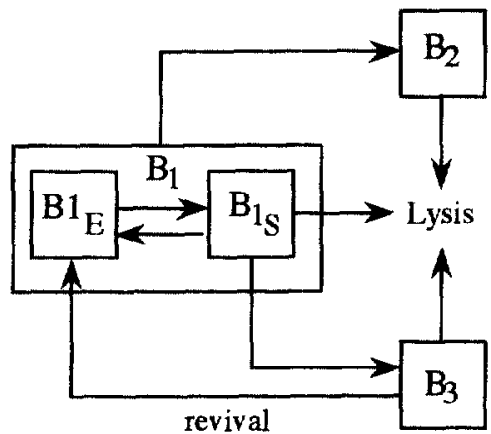

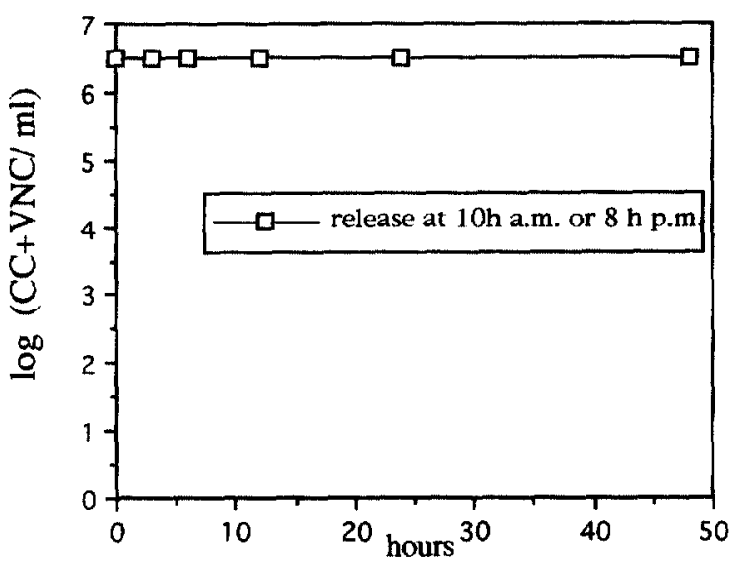

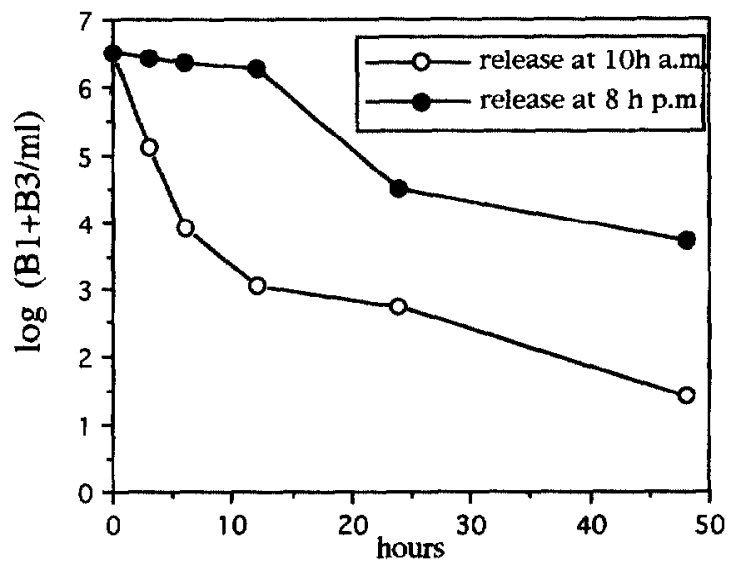

Figure 6. Schematic representation of three conceptual models of $E$. coli behaviour in the marine environment and simulation of abundance changes in the considered cellular states in relation to their release time in seawater. 
Table VI. Estimation of the proportion of the three cellular states computed from different cell count procedures (see text) during two different survival conditions.

\begin{tabular}{rccccccccc}
\hline \multicolumn{2}{c}{} & \multicolumn{2}{c}{$\mathrm{OM}^{-} \mathrm{S}^{+} \mathrm{L}^{+}$} & & \multicolumn{3}{c}{$\mathrm{OM}^{-} \mathrm{S}^{+} \mathrm{L}^{-}$} \\
\hline Dt & $\mathbf{B}_{\mathbf{1}} \%$ & $\mathbf{B}_{\mathbf{2}} \%$ & $\mathbf{B}_{\mathbf{3}} \%$ & & $\mathbf{D t}$ & $\mathbf{B}_{\mathbf{1}} \%$ & & $\mathbf{B}_{\mathbf{2}} \%$ & $\mathbf{B}_{\mathbf{3}} \%$ \\
\hline $0 \mathrm{~h}$ & 100 & 0.0 & 0.0 & & $0 \mathrm{~h}$ & 100 & 0 & 0.0 \\
$6 \mathrm{~h}$ & 1.8 & 98.2 & 0.0 & & $24 \mathrm{~h}$ & 14.1 & 85.9 & 0.0 \\
$72 \mathrm{~h}$ & $1.610^{-4}$ & 99.9 & 0.098 & & $72 \mathrm{~h}$ & 0.12 & 99.77 & 0.28 \\
\hline
\end{tabular}

The "physiological adaptation" model has been shown to predict changes in culturable cell $\left(B_{1}\right)$ abundance accurately. $B_{2}$ and $B_{3}$ cell abundance are more difficult to measure due to the lack of unambiguous methodologies to detect and enumerate these cellular states [43]. As a first approach, we can combine the results of different cell count procedures (total counts (TC), culturable counts (CFU), and direct viable counts (DVC)) to try to estimate the abundance of the three cellular states of the model as follows: $B_{1}=\mathrm{CFU}, B_{3}=$ (DVC-CFU) and $B_{2}=$ (TCDVC). These data, obtained from microcosms exposed to sunlight during a $72 \mathrm{~h}$ experiment conducted in April 1996, provide the results reported in table VI. These results seem to agree with the model hypotheses absence of $B_{3}$ cells during the first hours of stress exposure, $B_{2}$ cells becoming dominant very quickly-and, of course, to confirm the existence of these cellular states. However, the ability of the model to accurately represent the $B_{2}$ and $B_{3}$ dynamics must be checked under other stress conditions. In addition, it is important to acquire

\section{REFERENCES}

[1] Almiron M., Link A., Furlong D., Kolter R., A novel DNA binding protein with regulatory and prospective roles in starved Escherichia coli, Genes Dev. 6 (1992) 2646-2654.

[2] Auer M.T., Niehaus S.L., Modeling fecal coliform bacteria, I Field and laboratory determination of loss kinetics, Wat. Res. 27 (1993) 693-701.

[3] Barcina I., Gonzalez M., Iriberi J., Egea L., Effect of visible light on progressive dormancy of Escherichia coli cell during the survival process in natural freshwater, Appl. environ. Microbiol. 55 (1989) 246-251.

[4] Bonnefont J.L., Martin Y., Guiennet B., Étude expérimentale de la décroissance des bactéries fécales en milieu marin, Quantification, facteurs impliqués, Wat. Res. 24 (1990) 267273.

[5] Bonnefont JL., Martin Y., Étude du devenir des bactéries test de contamination fécale dans l'eau de mer, Recherche de modèles de simulation, Sci. Tech. Technol. 18 (1991) 16-21.

[6] Brisou J., de Rautlin de la Roy Y., Rigomier D., Teneur en matière organique du milieu marin et vie microbienne, C.R. Soc. Biol. 159 (1965) 745. data on the long term behaviour of the cellular states and the essential problem of revival must be faced. This last point remains poorly documented. Even if reversal of the processes that resulted in nonculturability has been reported $[31,39,44,45]$, whether, and to what extent, dormant cells can really revert to a culturable state has yet to be conclusively demonstrated.

Consequently, even if this model leaves room for improvement, it may be viewed as a tool to synthesize and quantitatively test hypotheses regarding the biological mechanisms of survival behaviour. Concerning this last point, this model may also find applications for other species than indicator bacteria including autochthonous species of the marine environment.

\section{Acknowledgements}

This work was supported by the Programme National d'Océanographie Côtière (France).
[7] Caperon J., Meyer J., Nitrogen-limited growth of marine phytoplankton, Deep-Sea Res. 19 (1972) 601-632.

[8] Curtis T.P., Mara D., Silva S.A., Influence of Ph. oxygen, and humic substances of ability of sunlight to damage fecal coliforms in waste stabilization pond water, Appl. Environ. Microbiol. 58 (1992) 1335-1343.

[9] Dabes J.N., Finn R.K., Wilke C.R., Equations of substratelimited growth: the case for Blackman kinetics. Biotech. Bioeng. 15 (1973) 1159-1177.

[10] Davies C.M., Evison L.M., Sunlight and the survival of enteric bacteria in natural waters. J. Appl. Bacteriol. 70 (1991) 265274.

[11] Di Toro D.M., Applicability of cellular equilibrium and Monod theory to phytoplankton growth kinetics, Ecol. Modelling 8 (1980) 201-218.

[12] Droop M.R., The nutrient status of algal cells in continuous culture, J. Mar. biol. Assoc. U.K. 54 (1974) 825-855

[13] Garcia-Lara J., Menon P., Servais P., Billen G., Mortality of fecal bacteria in seawater, Appl. Environ. Microbiol. 57 (1991) $885-888$. 
[14] Gauthier M.J., Clément R.L., Effect of a slıort period of starvation in oligotrophic waters on the resistance of enteric bacterial pathogens to gastric pH conditions, FEMS Microbiol. Ecol. 14 (1994) 275-284.

[15] Gauthier M.J., Munro P.M., Breittmayer V.A., Influence of prior conditions on low nutrient responses of Escherichia coli in seawater, Can. J. Microbiol. 35 (1989) 379-383.

[16] Gauthier M.J., Flatau G.N., Clement R.L., Munro P.M., Sensitivity of Escherichia coli cells to seawater closely depends on their growth stage, J. Appl. Bact. 73 (1992) 257262.

[17] Gauthier M.J., Labedan B., Breittmayer V.A., Influence of DNA supercoiling on the loss of culturability of Escherichia coli cells incubated in seawater, Molecular Ecol. 1 (1992) $183-190$.

[18] Gauthier M.J., Munro P.M., Flateau G.N., Clement R.L., Breittmayer V.A., Nouvelles perspectives sur l'adaptation des entérobactéries dans le milieu marin, Mar. Life 3 (1-2) (1993) $1-18$.

[19] Gourmelon M., Cillard J., Pommepuy M., Visible light damage to Escherichia coli in seawater: oxidative stress hypothesis, J. Appl. Bacteriol. 77 (1994) 105-1 12.

[20] Grimes D.J., Atwell R.W., Brayton P.R., Palmer L.M., Rollins D.M., Roszack D.B., Singleton F.L., Tamplin M.L., Colwell R.R., The fate of enteric pathogenic bacteria in estuarine and marine environments, Microbiol. Sci. 3 (1986) $324-329$

[21] Hengge-Aronis R., The role of RpoS in early stationary phase gene regulation in Escherichia coli $\mathrm{K} 12$, in: Kjelleberg $\mathrm{S}$., (Ed), Starvation in bacteria, Plenum Press, New York and London, 1993, pp. 171-200

[22] Kaprelyants A.S., Gottschal J.C., Kell B.K., Dormancy in nonsporulating bacteria, FEMS Microbiol. Rev. 104 (1993) 271 286

[23] Kogure K., Simidu U., Taga N., A tentative direct microscopic method for counting living marine bacteria, Can. J. Microbiol. 25 ( I979) $415-420$.

[24] Kolter R., Life and death in stationary phase, ASM News 58 (1992) 75-79.

[25] Matin A., Physiology, molecular biology and applications of the bacterial starvation response, J. Appl. Bact. 73 (1992) $49 \mathrm{~S}-57 \mathrm{~S}$

[26] Menon P., Mortalité des bactérics allochtones rejetées dans les milieux aquatiques, Thèse Doct. Univ. Paris-VI (1993) 140 p.

[27] McGrew S.B., Mallette M.F., Energy of maintenance in Escherichia coli, J. Bacteriol. 83 (1962) 844-850

[28] Mc Kay A M., Viable but non-culturable forms of potentially pathogenic bacteria in water, Lett. Appl. Microbiol. 14 (1992) $129-135$.

[29] Morita R.Y., Biovailibility of energy and its relationship to growth and starvation survival in nature, Can. J. Microbiol. 34 (1988) 436-441.
[30] Morita R.Y., Bioavaibility of energy and lle starvation stale, in: S. Kjelleberg (Ed.), Starvation in bacteria, Plenum Press, New York and London, 1993, 1-23.

[31] Nilsson L., Oliver J.D., Kjelleberg S., Resuscitation of Vibrio vulnificus from the viable but nonculturable state, J. Bacteriol. 173 (1991) 5054-5059.

[32] Nyström T., Global systems approach to the physiology of the starved cell, in: S. Kjelleberg (Ed.), Starvation in bacteria, Plenum Press, New York and London, 1993 129-150.

(33) Uliver J.D., Formation of viable but nonculturable cells, in: S. Kjelleberg (Ed.), Starvation in bacteria, Plenum Press, New York and London, 1993 239-272.

[34] Panikov N.S., Microbia] growth kinetics, Chapman \& Hall. London, 1995, $378 \mathrm{p}$

[35] Ponmepuy M., Guillaud J.F., Martin Y.P., Dupray E., Derrien A., L'yavanc J., Cormier M., Le devenir des bactéries en zone littorale, in: La mer et les rejets urbains, IFREMER, Actes de colloques, 11 (1991) 89-100.

[36] Porter K.G., Feig Y.S., The use of DAPI for identifying and counting aquatic microflora, Limnol. Oceanogr. 25 (1980) $943-948$.

[37] Rhodes M.W., Kator H.l., Effects of sunlight and autochthonous microbiota on Escherichia coli survival in an estuarine environment, Curr. Microbiol. 21 (1990) 65-73.

[38] Roszak D.B., Colwell R.R., Survival strategies of bacteria in the natural environment, Microbiol. Rev. 51 (1987) 365-379.

[39] Roth W.G., I eckie M.P., Dietzler D.N., Restoration of colonyforming activity in osmotically stressed Escherichia coli by betaine, Appl. Environ. Microbiol. 54 (1988) 3142-3146.

[40] Servais P., Menon P., Fate of autochthonous and fecal bacteria in marine ecosystems, Kieler Meeresforsch. Sonderh. 8 (1991) $290-296$.

[41] Stevenson L.H., A case for bacterial dormancy in aquatic sys. tems, Microb. Ecol. 4 (1978) 127-133.

[42] Tormo A., Almiron M., Kolter R., Sur A, an Escherichia coli gene essential for survival in stationnary phase, J. Bact. 172 (1990) 4337-4339.

[43] Troussellier M., Bonnefont J.L., Courties C., Derrien A., Dupray E., Gauthier M., Gourmelon M., Joux F., Lebaron P., Martin Y., Pommepuy M., Responses of enteric bacteria to environmental stresses in seawater, Oceanol. Acta 21 (6) (1998) 965-981.

[44] Votyakova T.V., Kaprelyants A.S., Kel] D.B., Influence of viable cells on the resuscitation of dormant cells in Micrococcus lateus culture held in an extended stationary phase: the population effect, Appl. environ. Microbiol., 60 (1994) 3284-3291.

[45] Xu H.S., Roberts N., Singleton F.L., Atwell R.W., Grimes D.J., Colwell R.R., Survival and viability of nonculturable Escherichia coli and Vibrio cholerae in the estuarine and marine environment, Microb. Ecol. 8 (1982) 313-323. 